\title{
PREFACE
}

I have been passionate about college journalism since high school. As a junior and senior, I treasured the visits I made with my father to campuses throughout Greater Philadelphia and beyond. There is simply something about a lively college campus that puts a smile on my face and a giddyup in my heartbeat. Some students on a college tour seek out the main academic buildings, the athletic facilities, the freshmen dorms. I searched for newsstands. I felt I learned more about the schools I visited through one issue of a quality student newspaper than from a full tour, admissions rep sit-down, and website visit, combined. When I selected a college, I immediately sent an e-mail to the student newspaper's faculty adviser requesting to be considered for the position of editor in chief. Okay, so I overshot a little. In my sophomore year, the dream came true. Cue the smile and the giddyup. Neither have let up since.

As a student, teacher, adviser, reporter, editor, blogger, and researcher, I have operated within the framework of the student journalism field and also explored the theories behind it and the issues that provide it with the power to transform lives, shape experiences, and offer meaning to the campus routine. Student media are absolutely integral to university life. Their audiences are impassioned. Innovation is occurring at an ever-faster clip. Free press fights rage on. The influence they exert within journalism and higher education has become boundless. And amid it all, they are oozing an electrifying, omnipresent sexuality that continually stirs the media and academia into a tizzy.

In an online comment following a story in The Nation last fall that identified me as a leading expert of the student press sexualization phenomenon, a snarky reader posted a question that I have been asked endlessly since embarking on this book project: "Wow. I wonder what it takes to become such an expert?" The question's sexual subtext always makes me laugh. To clarify, no, I did not seek to explore sex in the student press due to an overwhelming interest in sex or any deep-rooted sexual kinkiness or fetishisms. Instead, a few years ago I started noticing that more media coverage and free press fights 
were centering on student sex columns and sex magazines than on anything else within college journalism. It seemed that at schools across the United States and into Canada debates were happening about the pieces' and publications' eye-popping editorial content, earning them an array of conflicting labels: the Rx for sex, sexual bibles, literary moaning sessions, softcore porn bullshit, sexual soapboxes, sappy love babble, a state-of-the-romance address, and the latest journalistic frontier. I became curious. I went to Google, then LexisNexis, then individual student newspaper websites and library archives. I sent e-mails, made phone calls, and spoke with people face-to-face.

In general, I simply did what I wish more people would do with the student press: I cared enough to pay attention, close attention, and I did not stop until the complete story was told. My ultimate rationale for the book's existence is best summarized in the editorial note that opens the inaugural issue of Boink, the student sex magazine co-founded by a Boston University student: "Everyone knows sex sells. . . . And it sells because it's a basic and vital part of being human, like eating and sleeping . . . only more fun. Why shouldn't it be discussed as freely as what you had for dinner last night?"

The discussion laid out in these pages would not have been possible without the basic, vital support of my parents-accompanied by my brothers, grandparents, and an extended family so large and caring it takes two full days to celebrate Christmas. I am further indebted to two of my former teachers, Robert Dickinson and Jackie Koch. They inspired me to pursue writing as a passion and profession, especially Mrs. Koch. Whenever she looked at me, I loved the writer I saw reflected in her eyes. In many ways, I owe her everything.

My sincere gratitude extends to Patrick Washburn for his guidance and enthusiastic support of this project. An additional heartfelt thank-you to my editor, Leslie Mitchner, whose patient, insightful supervision helped shape this work into something I am proud to publish. This book stands on their shoulders. A final thanks to others who have been huge helps with this project or more general life inspirations: Albert Barbetta, Joseph Bernt, Rosemary Boccella, Marilyn Campbell, Lynne Edwards, Samuel Freedman, Wendy Greenberg, Carolyn Kitch, Mary Ellen Malloy, Andrew Mendelson, David Mould, Chester Pach, Daniel Riffe, Carol Robidoux, Jan Slater, John Strassburger, Den Sweeney, Nicholas Taylor, and Ed Trayes. 


\section{SEX and the UNIVERSITY}


